\title{
ANTIDEMOCRACY IN AMERICA
}




\section{Public Books Serieg}

Sharon Marcus and Caitlin Zaloom, Editors

Founded in 2012, Public Books is required reading for anyone interested in what scholars have to say about contemporary culture, politics, and society. The monographs, anthologies, surveys, and experimental formats featured in this series translate the online experience of intellectual creativity and community into the physical world of print. Through writing that exemplifies the magazine's commitment to expertise, accessibility, and diversity, the Public Books Series aims to break down barriers between the academy and the public in order to make the life of the mind a public good.

Think in Public: A Public Books Reader, edited by Sharon Marcus and Caitlin Zaloom, 2019

Antidemocracy in America: Truth, Power, and the Republic at Risk, edited by Eric Klinenberg, Caitlin Zaloom, and Sharon Marcus, 2019 


\section{ANTIDEMOCRACY IN AMERICA}

TRUTH, POWER,AND THE REPUBLIC AT RISK

Edited by

ERIC KLINENBERG

CAITLIN ZALOOM

SHARON MARCUS

COLUMBIA UNIVERSITY PRESS

NEW YORK 
Columbia University Press

Publishers Since 1893

New York Chichester, West Sussex

cup.columbia.edu

Copyright (C) 2019 Eric Klinenberg, Caitlin Zaloom, and Sharon Marcus

All rights reserved

Library of Congress Cataloging-in-Publication Data

Names: Klinenberg, Eric, editor. | Zaloom, Caitlin, editor. | Marcus,

Sharon, 1966- editor.

Title: Antidemocracy in America : truth, power, and the republic at risk / edited by Eric Klinenberg, Caitlin Zaloom, and Sharon Marcus.

Description: New York : Columbia University Press, [2019] | Series: Public books series | Includes bibliographical references.

Identifiers: LCCN 2018061396 (print) | LCCN 2019002481 (ebook) | ISBN 9780231548724 (e-book) | ISBN 9780231190107 (cloth : alk. paper) | ISBN 9780231190114 (pbk. : alk. paper)

Subjects: LCSH: United States-Politics and government-2017-

Conservatism-United States-History-21st century. | Trump, Donald, 1946- | Political culture-United States-21st century.

Classification: LCC E912 (ebook) | LCC E912.A58 2019 (print)|

DDC 306.20973/0905-dc23

LC record available at https://lccn.loc.gov/2018061396

Columbia University Press books are printed on permanent and durable acid-free paper.

Printed in the United States of America

Cover design: Julia Kushnirsky

Cover photo: Ted Eytan, MD

Book design: Lisa Hamm 